\title{
PELATIHAN PEMBUATAN VCO MENGGUNAKAN ISOLAT BAKTERI ASAM LAKTAT ASAL USUS AYAM DAN PEMANFAATAN LIMBAHNYA MENJADI PUPUK CAIR DI KELURAHAN JERAKAH SEMARANG
}

\author{
Siti Nur Jannah', Hermin Pancasakti Kusumaningrum², Rejeki Siti Ferniah ${ }^{3}$, dan Sri \\ Pujiyanto 4 \\ 1,2,3,4 PS. Bioteknologi, Dept. Biologi, Universitas Diponegoro. Jl. Prof Soedarto, Tembalang, Semarang \\ nurjannah.suroso@gmail.com, herminpk@live.undip.ac.id, ferniahmikro@gmail.com spbio92@gmail.com
}

\begin{abstract}
Abstrak
Semarang dengan berbagai kekayaan Sumber Daya Hayati (SDH) yang sangat melimpah, terutama dalam hal ini kelapa belum dimanfaatkan dan diolah secara optimal, sehingga kontribusinya dalam peningkatan ekonomi masyarakat masih belum dirasakan. Berdasarkan latar belakang tersebut, kami akan mengadakan kegiatan pengabdian kepada masyarakat melalui penerapan IPTEKS yang sudah kami lakukan dalam skala laboratorium, berupa diversifikasi produk olahan berbasis santan kelapa yang dapat digunakan untuk membuat VCO (Virgin Coconut $\mathrm{Oil}$ ). Tujuan program pengabdian masyarakat adalah mengaplikasikan teknologi fermentasi oleh bakteri asamlaktat menggunakan santan kelapa untuk pembuatan VCO dan pupuk cair di kelompok PKK dan guru-guru di Madrasah Ibtidaiyyah Walisongo Jerakah Semarang. Metodologi yang digunakan adalah penyuluhan dan praktek tentang pembuatan VCO dan penanganan limbahnya menjadi pupuk cair. Hasil dari Pengabdian ini adalah produk, metode/teknologi tepat guna, dan publikasi. Diharapkan pembuatan produk VCO dan pupuk cair yang dihasilkan memberi manfaat pengetahuan tentang fermentasi dan dapat digunakan sebagai usaha inisiasi bisnis bagi kelompok PKK dan guru di Jerakah Semarang.
\end{abstract}

Kata Kunci : bakteri asam laktat, jerakah, pupuk cair, santan kelapa, virgin coconut oil

\section{PENDAHULUAN}

Kotamadya Semarang merupakan kombinasi antara daerah pantai, dataran rendah dan pegunungan. Dengan kondisi ini Kotamadya Semarang mempunyai potensi yang sangat besar untuk agroindustri, agrowisata dan agrobisnis. Dengan adanya kondisi topografi yang beragam maka Semarang memiliki potensi untuk budidaya berbagai jenis tanaman, salah satunya kelapa. Kelapa (Hapsari, 2007).

Kotamadya Semarang dengan berbagai kekayaan Sumber Daya Hayati yang sangat melimpah, terutama dalam hal ini kelapa belum dimanfaatkan dan diolah secara optimal, terutama kelapa yang banyak tumbuh di lereng-lereng perbukitan, sehingga kontribusinya dalam peningkatan ekonomi masyarakat masih belum dirasakan. Berdasarkan latar belakang tersebut, kami akan mengadakan kegiatan pengabdian kepada masyarakat melalui penerapan IPTEKS berupa diversifikasi produk olahan berbasis santan kelapa yang dapat digunakan untuk membuat VCO (Virgin Coconut Oil). VCO mengandung asam laurat yang cukup tinggi sehingga minyak VCO memiliki beberapa manfaat, asam laurat dalam tubuh manusia diubah menjadi monolaurin dan yang menjadi paling kuat sebagai antivirus,

$$
\text { Teknologi Tepat Guna }
$$


antibakteri, antikapang dan antiprotozoa sehingga dapat menanggulangi serangan virus seperti HIV, herpes, influenza dan berbagai bakteri patogen, serta kemampuan untuk meningkatkan jumlah sel darah putih (Ghani et al., 2011; APCC, 2020).

Starter yang digunakan pada pembuatan VCO ini adalah isolat Bakteri asam laktat (BAL). BAL merupakan bakteri yang biasa berperan dalam pangan fermentasi dan terbukti mampu menginduksi proses pemisahan minyak dan air dari santan kelapa (Marina et al., 2009). Senyawa antimikroba yang dihasilkan BAL untuk menghambat bakteri patogen dan pembusuk itu antara lain adalah asam organik, peroksida, diasetil, CO2, dan bakteriosin (Jannah et al., 2018). BAL merupakan mikroorganisme yang Generally Recognized as Safe (GRAS) yaitu mikroorganisme yang tidak berisiko terhadap kesehatan (Heravi et al., 2011).

Manfaat VCO yang sangat besar bagi kesehatan dan kebutuhannya yang semakin meningkat menjadikan produk ini bisa dikembangkan di Kotamadya Semarang sebagai usaha agribisnis selain bertani dan berternak, sehingga dapat meningkatkan harga jual dan pada akhirnya dapat juga meningkatkan pendapatan masyarakat di Kotamadya Semarang. Tujuan program pengabdian masyarakat adalah mengaplikasikan teknologi fermentasi menggunakan santan kelapa untuk pembuatan VCO dan pemanfaatan limbahnya untuk pupuk cair di kelompok PKK dan para Guru di Madrasah Ibtidaiyyah Walisongo, Jerakah Semarang. Metodologi yang digunakan adalah penyuluhan dan praktek tentang pembuatan VCO (Virgin Coconut Oil) dan penanganan limbahnya menjadi pupuk cair. Luaran yang akan dihasilkan dari penelitian ini adalah produk, metode/teknologi tepat guna, dan publikasi. Diharapkan produk VCO yang dihasilkan akan merupakan usaha inisiasi bisnis bagi kelompok tani kelompok PKK dan para guru Jerakah Semarang tersebut.

\section{METODE}

Pada pengabdian Masyarakat ini akan dilakukan beberapa program kerja yang meliputi : pembuatan VCO melalui fermentasi santan kelapa dengan menggunakan bakteri asam laktat yang diisolasi dari usus ayam kampung dalam skala laboratorium, penyuluhan dan praktek pembuatan VCO di masyarakat, pemanfatan limbahnya menjadi pupuk cair, penyuluhan cara pengemasan yang baik dan hiegenis, penyuluhan dan pembinaan terhadap pemasaran produk yang akan dihasilkan.

Pembuatan VCO dimulai dengan persiapan media starter. Starter yang biakan murni dari bakteri asam laktat (BAL) asal usus ayam yang telah diidentifikasi oleh peneliti sebagai bakteri Lactobacillus paracasei. Pembuatan starter dengan cara isolat $L$. paracasei yang telah ditumbuhkan dalam media MRS cair ditambahkan $1 \mathrm{~mL}$ ke dalam skim milk $10 \%$, diinkubasi pada suhu $37^{\circ} \mathrm{C}$ selama 24 jam (overnight). Selanjutnya hasil starter tersebut yang akan digunakan untuk pembuatan VCO pada krim santan (Kotimah et al., 2018). Starter yang digunakan dalam pembuatan VCO dibuat sebanyak $200 \mathrm{ml}$ dalam erlenmeyer.

Produksi VCO melalui fermentasi secara dengan cara santan kelapa hasil perasan yang ada di wadah fermentasi (baskom/ember plastik bening) ditambah dengan air mendidih dengan jumlah santan dan air 4:1 kemudian ditambahkan starter unur 24 jam L. paracasei $1 \%$, inkubasikan selama 24 jam dalam suhu $37^{\circ} \mathrm{C}$. Selanjutnya akan terbentuk tiga lapisan pada hasil fermentasi, lapisan pertama berada paling bawah adalah air, lapisan kedua berada ditengah adalah blondo dan lapisan ketiga yang paling atas minyak VCO. Minyak ditampung di tempat bersih dan hieginis dengan cara disaring terlebih dahulu dengan kertas saring dan kapas. Minyak VCO dikemas dalam botol plastik dan diberi label kertas (Harni dan Putri, 2014; Suryani, et al., 2020). 


\section{HASIL DAN PEMBAHASAN}

\section{Persiapan starter VCO di Laboratorium Bioteknologi.}

Starter berupa isolat L. paracasei ditumbuhkan dalam medium susu skim 10\%, karena media susu skim lebih murah, mudah diperoleh, dan langsung dapat diterapkan ke produk pangan. Starter bakteri yang telah siap digunakan mengandung jumlah bakteri asam laktat dengan konsentrasi minimum $10^{6}$ CFU/mL (Sodini, et al., 2002).

\section{Penyuluhan dan praktek pembuatan VCO}

Kegiatan Pengabdian masyarakat untuk kelompok Ibu-ibu PKK kelurahan Jerakah dimulai dengan mengunjungi ibu-ibu PKK kelurahan Jerakah untuk mencari informasi dan kemungkinan pemecahan masalah yang bisa diterapkan pada pemberdayaan melalui kewirausahaan yang berbasis sumberdaya alam yang terdapat di kotamadya Semarang. Kegiatan penyuluhan dan praktek pembuatan VCO dan pemanfaatan limbahnya untuk pupuk cair dilakukan 2 seri, seri pertama dilakukan pada hari 28 Februari 2019 di rumah ibu Dra. Hj. Nur Aini dengan dihadiri 26 ibu-ibu PKK Jerakah dan tim pelaksana. Ibu-ibu PKK sebagian besar merupakan ibu-ibu rumah tangga yang mempunyai waktu luang setelah kegiatan rutinitas di rumah. Selanjutnya pada seri ke-2 dilakukan di Madrasah Ibtidaiyyah Walisongo, Jerakah pada tanggal 19 Agustus 2020 yang diikuti oleh 12 guru MI Walisongo Semarang (Gambar 1.).

Acara Penyuluhan ini diisi dengan cara presentasi dengan menggunakan LCD dan pembagian fotocopy slide dan informasi produk (product knowledge), sehingga para peserta dapat lebih jelas menerimanya. Pada waktu diskusi para peserta sangat antusias mendengarkan dan berdiskusi dengan para pemateri. Mereka menjadi lebih mengerti tentang manfaat VCO secara ilmiah, konsep VCO bekerja dalam tubuh, proses pembuatan VCO yang benar, syarat kesehatan untuk VCO yang dapat digunakan sebagai suplemen kesehatan, ketepatan penggunaan baik dosis dan waktunya, cara penggunaan, hieginitas lingkungan dan pekerja, kedaluwarsa VCO, dan pengemasan VCO yang baik.

\section{Pemantauan terhadap hasil pengabdian}

Setelah dilakukan penyuluhan pembuatan VCO dilakukan pemantauan terhadap hasil praktek pembuatan VCO dengan mencoba produk VCO dan diskusi serta tanya jawab. Peserta sangat antusias bertanya dan menanggapi masalah yang mungkin akan ditemui peserta. Pemantauan juga dilakukan dengan pengambilan sampel secara acak untuk mengisi kuesioner yang disediakan panitia.

Dari hasil pemantauan melalui kuesioner terlihat bahwa peserta belum pernah memperoleh pengetahuan pembuatan VCO, bahkan banyak yang belum mengetahu apa itu VCO, hal ini ditunjukkan dengan sebagian besar sangat setuju dan setuju dari kuesioner yang menyatakan materi pelatihan belum pernah diperoleh sebelumnya, terlihat dari antusiasme para peserta untuk hadir pada acara pelatihan. Dari hasil kuesioner menyatakan peserta mampu menyerap teknologi tepat guna yang diberikan dalam pembuatan VCO dan pemanfaatan limbahnya untuk pupuk, hal ini terlihat dari respon peserta $50 \%$ setuju dan $50 \%$ sangat setuju pada kuesioner dan telah dapat memahami teknik yang diberikan dan mampu mempraktekkan pembuatan VCO yang hiegines dan dapat mengendalikan titiktitik kritis dalam pembuatannya, sehingga dihasilkan produk VCO yang baik sesuai yang dipraktekkan. Hasil kuesioner juga membuktikan bahwa penyuluhan dan praktek pembuatan VCO telah memenuhi keinginan/harapan sebagian peserta dan para peserta menginginkan diberi pengetahuan dan praktek tentang produk-produk lain sebagai pengembangan dari produk VCO, seperti pembuatan sabun dari VCO dan produk-produk lain yang berbahan baku sumber daya alam lokal yang dapat menunjang perekonomian mereka. Dan mereka juga menginginkan cara pengemasan yang baik, higienis dan cara pemasarannya.

Tempat penyelenggaraan kegiatan yang mudah dijangkau menurut mereka sangat disukai

$$
\text { Teknologi Tepat Guna }
$$


dibandingkan tempat lain meskipun tempat lain yang lebih sesuai untuk praktek, misalnya di laboratorium kampus. Hal ini menunjukkan bahwa peserta merasa senang mengikuti acara setelah mereka melakukan pekerjaan rutin mengurus rumah tangga.

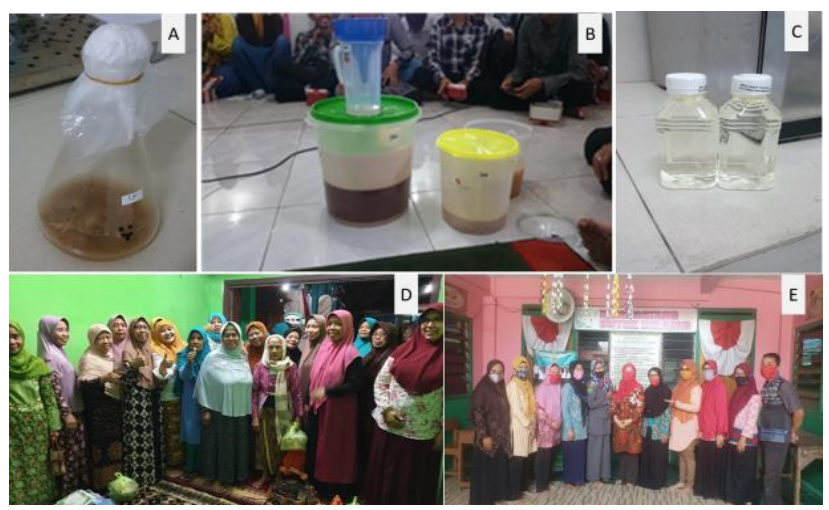

Gambar 1. Kegiatan penyuluhan dan pembuatan VCO di kelurahan Jerakah (A. starter isolat BAL, B.

Demo pembuatan dan penyaringan $\mathrm{VCO}, \mathrm{C}$. VCO yang sudah dikemas dalam botol, D. Foto bersama ibu-ibu PKK, E. Foto bersama dengan guru MI Walisongo kel. Jerakah

\section{KESIMPULAN}

Pengabdian kepada masyarakat yang telah dilaksanakan merupakan kegiatan dalam rangka pemberdayaan peserta di kelompok Ibu-ibu PKK dan guru MI Walisongo, kelurahan Jerakah Semarang dalam menambah pengetahuan dan keterampilan berwirausaha dan menaikkan tingkat perekonomian melalui pemanfaatan sumber daya alam lokal daerah tersebut. Pelaksanaan pengabdian tepat sasaran dan berjalan dengan lancar sesuai tujuan dan harapan yang diinginkan..

\section{UCAPAN TERIMAKASIH}

Ucapan terimakasih disampaikan kepada Fakultas Sains dan Matematika yang telah memberikan kontribusi dalam pelaksanaan kegiatan dengan dana DIPA Pengabdian tahun anggaran 2020 .

\section{REFERENSI}

APCC, 2010. Coconut Statistical Year Book 2009. Asian and Pacific Coconut Community [APCC]. Jakarta.

Ghani, NAA, Channip, AA, 1 , Hwa, PCH, Ja'afar F. (2018). Physicochemical properties, antioxidant capacities, and metal contents of virgin coconut oil produced by wet and dry processes. Food Sci Nutr. 6(5): 1298-1306.

Jannah, SN, Saraswati, TR, Handayani, D, Pujiyanto, S. 2018. Antibacterial Activity of Lactic Acid Bacteria Isolated from Gastrointestinal Tract of "Ayam Kampung"Chicken Against

Food

Pathogens. IOP Conf. Series: Journal of Physics: Conf. Series 1025 (2018) 012082

Hapsari, P. (2007). Identifikasi Komoditi Pertanian Unggulan Di Kabupaten Semarang.

Skripsi. Fakultas Pertanian, Universitas Sebelas Maret. Surakarta.

Harni, M, Putri, SK. 2014. Processing Methode Effect to Virgin Coconut Oil (VCO) Quality After Storaging. International Journal on Advanced Science, Engineering and Information

Technology. 4:2, DOI: $\quad$ http://dx.doi.org/ 10.18517/ijaseit.4.2.369

Heravi, RM, Kermanshahi H., Sankian M., Nassiri MR, Moussavi AH, Nasiraii LR, \& Varasteh AR. 2011. Screening of lactobacilli bacteria isolated from gastrointestinal tract of broiler chickens for their use as probiotic. African J. of Microbiol. Res. 5:1858-1868.

Khotimah, H, Baniyah, L, Hanafi I, Wardani, PWA, Sari, SMM, dan Jannah, SN. (2018). Pemanfaatan Bakteri Asam Laktat yang Di Isolasi Dari Saluran Pencernaan Ayam Lokal Untuk Pembuatan VCO Secara Fermentasi. Bioma. 1(20):35-39. 
Marina, AM; Che Man, YB and Amin I. Virgin coconut oil: emerging functional food oil. Review. 2009. Food Science \& Technology $20: 481-487$.

Sodini, Lucas A, Oliveira, MN. Remeuf, F and Corrieu, G. 2002. Effect of Milk Base and Starter Culture on Acidification, Texture, and Probiotic Cell Counts in Fermented Milk Processing. Journal of Dairy Science, 85:10, 2479-2488

Suryani, S, Sariani, S, Earnestly, F, Marganof, M, Rahmawati, R, Sevindrajuta, S. Mahlia, TMI and Fudholi, A. 2020. A Comparative Study of Virgin Coconut Oil, Coconut Oil and Palm Oil in Terms of Their Active Ingredients. Processes, 402; doi:10.3390/pr8040402.

Villarino, B. J., Dy, L. M., \& Lizada, C. C. (2007). Descriptive sensory evaluation of virgin coconut oil and refined, bleached and deodorized coconut oil. Food Science and Technology 40:19319. 